\title{
Development and validation of an assay for urinary tissue factor activity
}

\author{
B A Lwaleed, M Chisholm, J L Francis
}

\begin{abstract}
Background-Activation of blood coagulation is a common complication of cancer and inflammation in both humans and experimental animals. Increased production of tissue factor-the principal initiator of the coagulation process-by endothelial cells, monocytes, and macrophages has been implicated in these conditions.

Aim-To investigate whether urinary tissue factor (uTF) might reflect the state of monocyte/macrophage activation and be a useful diagnostic test.

Methods-Urine was centrifuged at $51000 \mathrm{~g}$ to sediment tissue factor containing membrane vesicles. The tissue factor was then solubilised in $\beta$-octylglucopyranoside and assayed in a specific chromogenic assay adapted for use in microtitre plates.

Results-The assay proved to be sensitive, specific, and reproducible. The normal range of $\mathrm{UTF}$ was relatively narrow and unaffected by age, sex, or cigarette smoking. Levels were not significantly influenced by storage of urine samples before assay or by the presence of fresh blood in the urine sample

Conclusions-This method may have diagnostic application in the study of haemostatic activation in patients with cancer and other disease states.

(F Clin Pathol 1999;52:219-224)
\end{abstract}

Keywords: tissue factor; urinary procoagulant; laboratory methods

University

Department of

Haematology,

Southampton

University Hospitals,

Southampton

SO16 6YD, UK

B A Lwaleed

M Chisholm

Hemostasis and

Thrombosis Research

Unit, Walt Disney

Memorial Cancer

Institute at Florida

Hospital, Altamonte

Springs, FL 32701,

USA

J L Francis

Correspondence to:

Dr Lwaleed.

Accepted for publication 20 November 1998 later found that urinary procoagulant activity activates prothrombin only in the presence of platelet factor 3 , factor $\mathrm{V}$, and calcium ions. It was therefore classified as "platelet cofactor" rather than tissue factor. ${ }^{13}$ More recently, Carty et al confirmed that the procoagulant was tissue factor. ${ }^{14}{ }^{15}$ The exact source of urinary tissue factor (uTF) is not yet known. However, it probably originates within the kidney, rather than being blood borne and passively filtered by the kidneys. ${ }^{16}$

Since monocyte tissue factor is often increased in cancer, ${ }^{9}$ we reasoned that the presence of tissue factor in urine may reflect a state of general monocyte/macrophage activation in disease states. Carty et al reported increased UTF levels in patients with colorectal cancer, inflammatory bowel disease, and breast cancer. ${ }^{14}{ }^{15}$ Patients with benign colorectal and breast disease also had increased concentrations when compared with normal controls but not with patients with malignant disease. In subsequent studies, however, (unpublished) we failed to confirm some of our earlier findings. Specifically, we could not differentiate between malignant colorectal or breast disease and normal or non-malignant surgical controls. More recently, Adamson et al reported increased concentrations of UTF in patients with transitional cell carcinoma of the bladder and prostate compared with controls and patients with benign prostatic hypertrophy. ${ }^{17} 18$

Having studied uTF for several years, particularly in cancer, we have noted variable and poorly reproducible results. This variability may be caused by factors such as poor assay reproducibility and the relative instability of tissue factor in urine. This has resulted in a wide normal range which makes statistical comparisons with patient groups difficult. In this study we aimed to optimise the assay of uTF activity, improve reproducibility, increase the stability of stored samples, and study some of the factors affecting uTF measurements.

\section{Methods}

SAMPLE COLLECTION AND PREPARATION

Urine samples were collected from each subject into sterile universal containers without preservative, before being processed and assayed for tissue factor activity. A $1 \mathrm{ml}$ sample of urine was placed in a $1.5 \mathrm{ml}$ microcentrifuge tube and centrifuged at $51000 \mathrm{~g}$ for 90 minutes at $4^{\circ} \mathrm{C}$. The supernatant was discarded and the pellet solubilised in $1 \mathrm{ml}$ of 15 $\mathrm{mM} \beta$-octyl-glucopyranoside (BOG; Sigma) by vortex mixing. The sample was then mixed slowly for 30 minutes at room temperature to ensure complete solubilisation. 
ASSAY PROCEDURE

uTF activity was measured by a one stage kinetic chromogenic method modified from that used by other workers. ${ }^{19} \mathrm{uTF}$, in the presence of recombinant factor VIIa (rf VIIa) and $\mathrm{Ca}^{2+}$, forms a complex which then directly activates factor X to factor Xa. Generation of factor $\mathrm{Xa}$, which is proportional to the amount of tissue factor in the urine sample, is determined by measuring its action on a factor Xa specific chromogenic substrate.

The assay was conducted, in duplicate, in flat bottomed 96 well microtitre plates. Each well contained $20 \mu \mathrm{l}$ purified factor X (American Diagnostica Inc; $100 \mathrm{nM}$ final concentration (fc)), $10 \mu \mathrm{rFVIIa}$ (Novo Nordisk A/S; $10 \mathrm{nM}$ fc), $20 \mu \mathrm{l}$ Spectrozyme Xa (American Diagnostica Inc; $0.5 \mathrm{mM}$ fc), $20 \mu \mathrm{l}$ of $\mathrm{CaCl}_{2}(10 \mathrm{mM}$ fc), $20 \mu \mathrm{l}$ of urine (processed as described above or unprocessed) sample and $90 \mu \mathrm{l}$ of factor $\mathrm{X}$ assay buffer (Tris- $\mathrm{NaCl} \mathrm{pH}$ 8.0, Diagnostica Stago). Blank wells contained the above reagents with $20 \mu \mathrm{l}$ of assay buffer instead of factor $\mathrm{X}$. The rate of reaction at $405 \mathrm{~nm}$ was determined in a Biokinetics EL-312e microplate reader (Bio Tek Instruments Inc), programmed to read the absorbance at 30 second intervals over a period of 35 minutes.

EFFECT OF SOLUBILISATION ON URINARY TISSUE FACTOR ACTIVITY

A $20 \mathrm{ml}$ sample of urine was collected from each of six healthy volunteers; $10 \mathrm{ml}$ of each sample was sedimented and solubilised as described above, while the other half was held at $4^{\circ} \mathrm{C}$. The processed and native samples were then assayed for tissue factor activity as described above.

OPTIMISATION OF THE ASSAY

The assay was optimised using known concentration of recombinant tissue factor (rTF; 0.15 ng fc; American Diagnostica Inc), relipidated

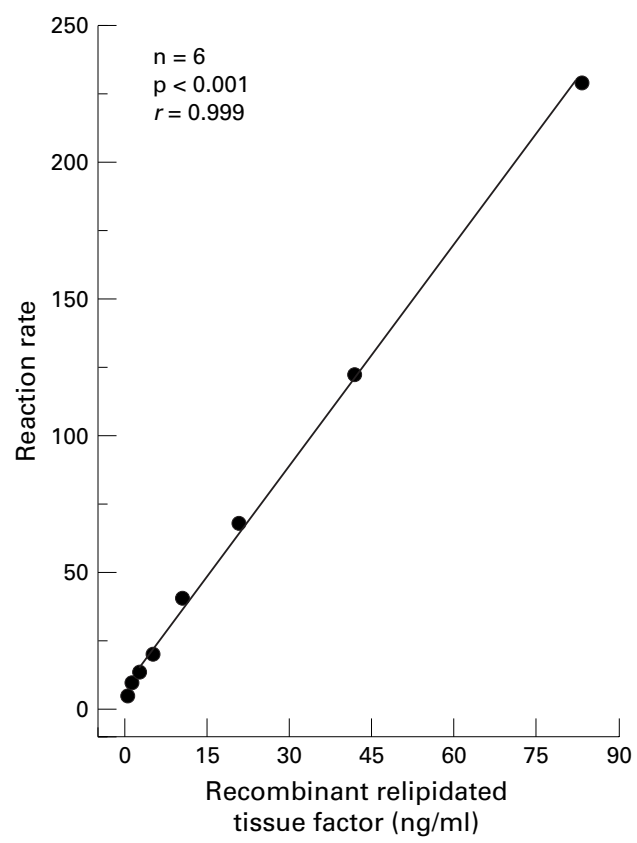

Figure 1 A typical standard curve for the chromogenic tissue factor assay. in this laboratory according to Carson and Konigsberg. ${ }^{20}$ The optimisation of the assay was achieved by altering six different variables separately: Factor X: 50-3200 nM. Recombinant Factor VIIa: 1-100 nM. Spectrozyme Xa: 0.03-2.1 mM. Calcium: 20-55 mM. $p H$ : 5.0-10.0. Final $\mathrm{pH}$ was measured in microplate wells (total volume $180 \mathrm{ml}$ ) using an Ingold microelectrode. Ionic strength: 0.0-400 $\times$ $10^{-3}$.

PREPARATION OF STANDARD CURVE

Serial dilutions of recombinant relipidated tissue factor ( $\mathrm{rrTF}, 0.4-83 \mathrm{ng} / \mathrm{ml}$ ) in BOG were made; $20 \mathrm{ml}$ of each standard were added to duplicate wells of a microtitre plate and activity measured as detailed above. A standard curve was constructed and used for the calculation of unknown uTF concentrations (fig 1). The results were corrected for urinary creatinine (see later).

STORAGE STABILITY OF RECOMBINANT RELIPIDATED TISSUE FACTOR AND NATIVE AND PROCESSED URINE SAMPLES

Short term

Aliquots of $\operatorname{rrTF}(20 \mu \mathrm{l})$ were placed into microcentrifuge tubes and stored at room temperature, $4^{\circ} \mathrm{C},-20^{\circ} \mathrm{C}$, or $-72^{\circ} \mathrm{C}$. Urine samples were collected from eight healthy volunteers. Half of each sample was immediately sedimented and solubilised with BOG as detailed above. Aliquots $(20 \mu \mathrm{l})$ of native and processed urine were then stored at $4^{\circ} \mathrm{C}$, $-20^{\circ} \mathrm{C}$, and $-72^{\circ} \mathrm{C}$. All were assayed as described above after $0,2,4,6,8$, and 12 hours of storage.

\section{Long term}

The experiment described above was repeated, but samples were assayed daily for seven days after collection and preparation at $4^{\circ} \mathrm{C},-20^{\circ} \mathrm{C}$, and $-72^{\circ} \mathrm{C}$. Since prolonged storage of urine at room temperature was unlikely to be appropriate, only cold and frozen storage was investigated.

THE EFFECT OF URINE CONCENTRATION ON URINARY TISSUE FACTOR ACTIVITY

Since creatinine concentration is a simple and reliable indicator of urine concentration, results of UTF activity were corrected for creatinine. Creatinine was assayed using a commercially available kit (Sigma). Early morning mid-stream urine samples were collected from 13 healthy volunteers and served as "concentrated" samples. The volunteers were then asked to drink $1500 \mathrm{ml}$ of water over a period of 15 minutes. The second urine sample passed from the time of drinking the water was considered a "dilute" sample. Both concentrated and dilute samples were then assayed as described above for uTF activity and corrected for urinary creatinine concentration as follows: $\mathrm{uTF}(\mathrm{ng} / \mathrm{ml}) /$ creatinine $(\mathrm{mg} / \mathrm{dl}) \times 100$.

CHARACTERISATION OF URINARY TISSUE FACTOR ACTIVITY

Urine was incubated with monoclonal antibody against human tissue factor $(15 \mathrm{mg} / \mathrm{ml} \mathrm{fc}$; 
American Diagnostica Inc), polyclonal goat antibody to human tissue factor $(15 \mathrm{mg} / \mathrm{ml} \mathrm{fc}$; American Diagnostica Inc), concanavalin A (70 $\mathrm{mg} / \mathrm{ml} \mathrm{fc}$; Sigma), phospholipase C (70 $\mathrm{mg} / \mathrm{ml} \mathrm{fc}$; Sigma) or rabbit anti-factor VII (10 units/ml fc; Diagnostica Stago) for 30 minutes at $37^{\circ} \mathrm{C}$. Aliquots were then assayed for uTF activity as detailed above. $\operatorname{rrTF}$ served as a positive control.

FACTORS AFFECTING URINARY TISSUE FACTOR ACTIVITY

Cellular debris

A $20 \mathrm{ml}$ sample of urine was collected from six healthy volunteers. Half of each sample was centrifuged at $2000 \mathrm{~g}$ for 10 minutes, while the other half was held at $4^{\circ} \mathrm{C}$. The supernatants of the spun samples as well as the native (original) samples were then processed and assayed for uTF activity as described above.

Diurnal and daily variation

Urine samples were collected from six healthy volunteers and the tissue factor activity measured immediately after collection and then at three hourly intervals for 15 hours. In addition, early morning mid-stream urine from seven healthy volunteers was collected and assayed for tissue factor on seven consecutive days.

Effect of blood on urinary tissue factor activity Six normal urine samples were spiked with 10 $\mu \mathrm{l}$ of blood. Each spiked sample was then serially diluted $1: 2,1: 4,1: 8,1: 16$, and $1: 32$ with additional urine from the same sample to give a total of five different levels of "haematuria." A control sample containing $10 \mu \mathrm{l}$ of assay buffer was also processed for each sample to determine baseline activity. All samples were thoroughly mixed and then incubated for one hour at $37^{\circ} \mathrm{C}$. Each sample was then assayed for uTF activity as detailed above.

STATISTICAL ANALYSIS

Data were analysed by the Statgraphics ${ }^{\mathrm{TM}}$ statistical software system. Results were nor-

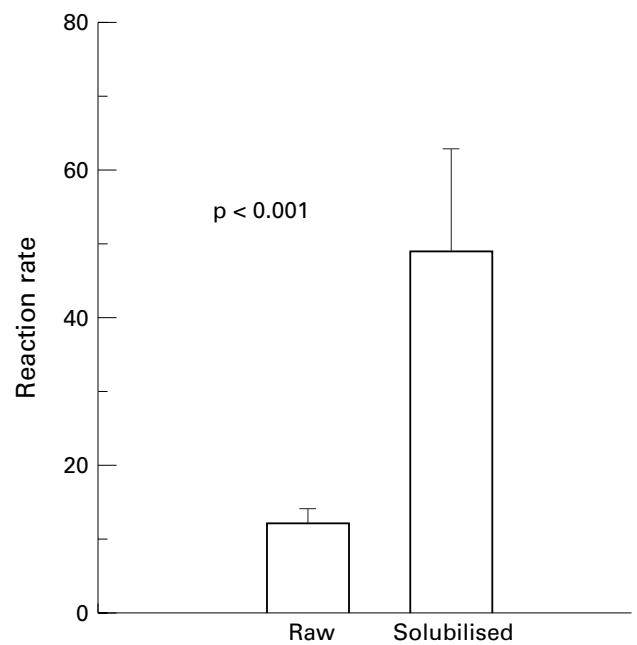

Figure 2 The effect of detergent processing on urinary tissue factor (uTF) activity in six healthy volunteers. Values were derived from native and processed samples. Error bars $=S D$. mally distributed and expressed as mean (SD). Differences between groups were assessed using Student's $t$ test and one way analysis of variance (ANOVA). Correlation was performed by simple regression analysis test.

\section{Results}

REPRODUCIBILITY OF THE ASSAY

The assay reproducibility was determined for both rrTF and uTF. The intra-assay coefficients of variation (CV) for both sources of tissue factor were $3.0 \%$ and $2.3 \%$, respectively; the corresponding figures for interassay variation were $4.3 \%$ and $8.1 \%$. These data indicate that the assay was acceptably reproducible.

EFFECT OF SOLUBILISATION

Most of the tissue factor in the urine sample was sedimentable by high speed centrifugation. Processing the pellet markedly increased the assayable tissue factor in the urine sample compared to the activity in unprocessed samples $(p<0.001$; fig 2$)$.

OPTIMISATION OF THE CHROMOGENIC ASSAY

Factor $X$ concentration-Reaction rate was linear over a wide concentration range (50$3200 \mathrm{nM}$ ). A concentration of $100 \mathrm{nM}$ was chosen.

Recombinant factor VIIa concentrationReaction rate was linear over the range $0-10$ $\mathrm{nM}$; a concentration of $10 \mathrm{nM}$ was chosen.

Spectrozyme Xa concentration - Reaction rate was linear to a concentration of $0.5 \mathrm{mM}$; this concentration was therefore used in subsequent experiments.

Calcium concentration-Reaction rate was linear to $10 \mathrm{mM}$, after which a significant drop in activity was observed. This concentration was therefore considered optimal.

$p H$-Activity increased with $\mathrm{pH}$ up to 8.0, above which it gradually declined. This value was therefore used in subsequent experiments.

Ionic strength - Reaction rate decreased with decreasing ionic strength. A value of $40 \times 10^{-3}$ was optimal.

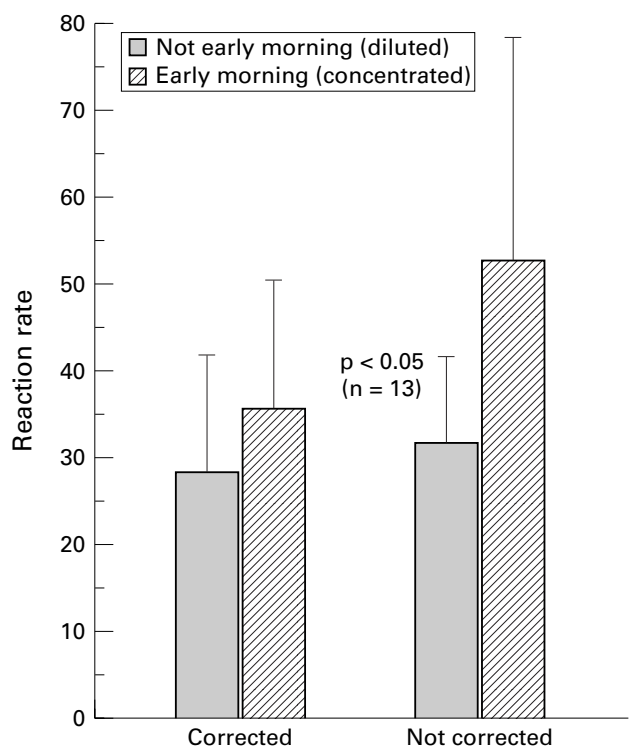

Figure 3 The effect of urine concentration on urinary tissue factor ( $U T F)$ activity. Error bars $=S D$. 


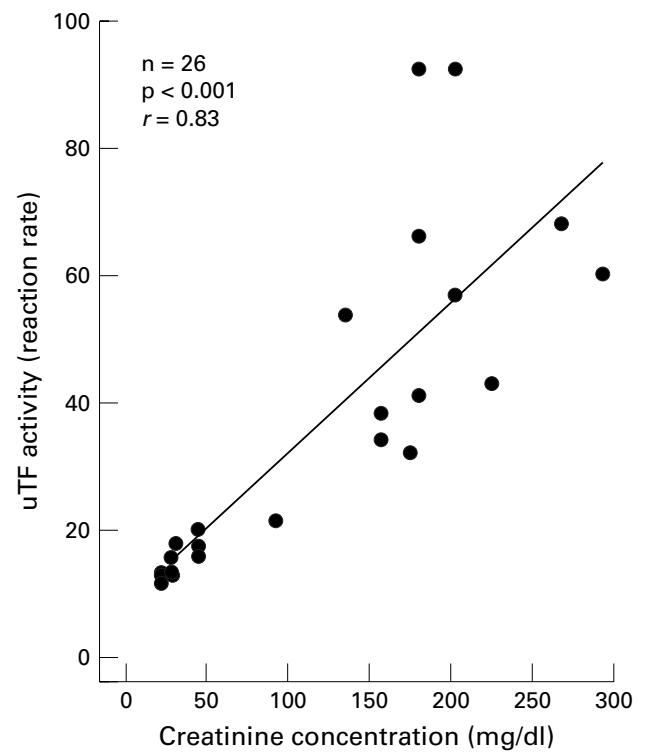

Figure 4 The relation between urinary tissue factor (uTF) activity and creatinine concentration.

STORAGE STABILITY OF RECOMBINANT RELIPIDATED TISSUE FACTOR, NATIVE AND PROCESSED URINE SAMPLES

Short term

Both rrTF and processed uTF were relatively stable at $4^{\circ} \mathrm{C},-20^{\circ} \mathrm{C}$, and $-72^{\circ} \mathrm{C}$. Rapid freezing reduced tissue factor activity by about $10 \%$ compared with the unfrozen value, after which it remained stable. Urine stored at $4^{\circ} \mathrm{C}$ remained stable for 24 hours, although a statistically non-significant fall in activity appeared after eight hours. Overall, there was no significant reduction in the activity (ANOVA). Unprocessed urine stored at $4^{\circ} \mathrm{C},-20^{\circ} \mathrm{C}$, and $-72^{\circ} \mathrm{C}$ before assay gave the same pattern as processed stored samples.

Long term

No meaningful reduction in tissue factor activity occurred after 24 hours. In detail, after storage for one day at each temperature $\left(4^{\circ} \mathrm{C},-20^{\circ} \mathrm{C}\right.$, and $-72^{\circ} \mathrm{C}$ ) there was an average reduction of

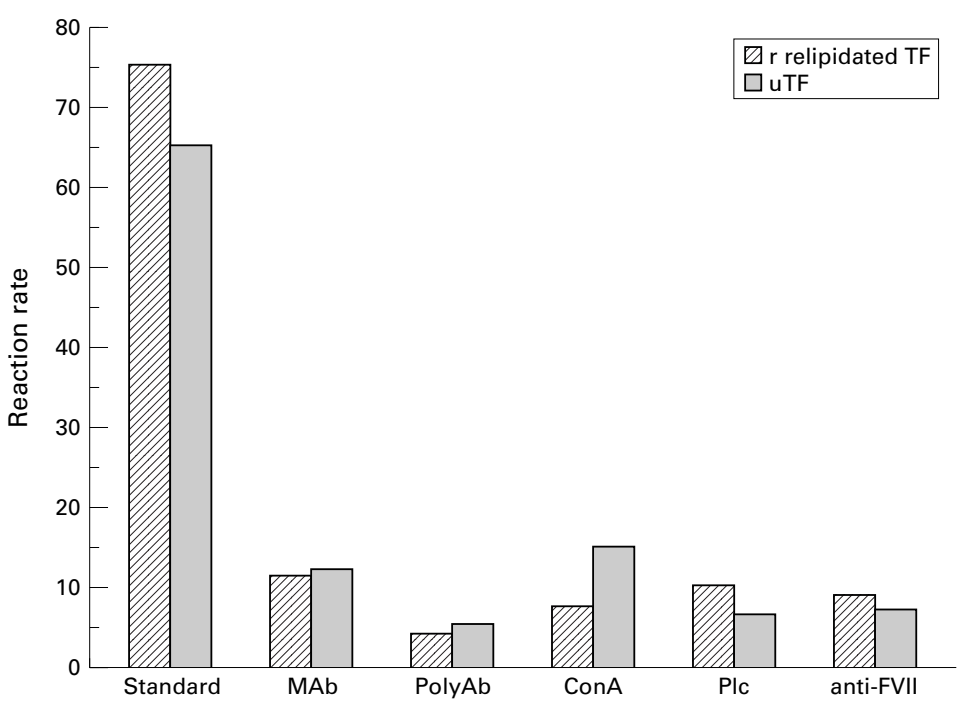

Figure 5 Characterisation of urinary tissue factor $(u T F)$ activity. The bars represent the mean value for each group. $r$, recombinant. between $10 \%$ and $15 \%$ in tissue factor activity. This was followed by a gradual return to the original value over the next seven days. These changes, however, did not at any stage reach individual statistical significance (ANOVA).

EFFECT OF URINE CONCENTRATION ON URINARY TISSUE FACTOR ACTIVITY

Diluted urine showed a significant reduction in tissue factor activity $(\mathrm{p}<0.001)$. However, when the samples were corrected for urine concentration by measuring creatinine, this difference was significantly reduced (fig 3). There was a significant correlation between uTF activity and creatinine concentration $(\mathrm{p}<0.001 ; r=0.83$; fig 4$)$.

\section{CHARACTERISATION OF URINARY TISSUE FACTOR} ACTIVITY

As shown in fig 5, the activity of both $\operatorname{rrTF}$ (positive control) and uTF were significantly inhibited $(\mathrm{p}<0.001)$ by monoclonal and polyclonal antibodies to human tissue factor, concanavalin A, and phospholipase C. The activity was also significantly reduced by a rabbit antibody to factor VII.

FACTORS AFFECTING URINARY TISSUE FACTOR ACTIVITY

Age, sex, and smoking

There was no significant difference in uTF excretion in normal controls divided into two age groups (mean uTF in group $1,7.7 \mathrm{ng} / \mathrm{ml}$ (2.0-12.0), $\mathrm{n}=31$; mean uTF in group $2,8.9$ $\mathrm{ng} / \mathrm{ml}(4.3-13.0), \mathrm{n}=26)$, nor was there a significant correlations between age and uTF activity $(\mathrm{n}=57, r=0.23, \mathrm{p}>0.05)$. Mean uTF in males (8.3 ng/ml (4.3-15.0), $\mathrm{n}=30$ ) was not significantly different from that found in females $(8.4 \mathrm{ng} / \mathrm{ml}(6.0-13.0), \mathrm{n}=27)$. Also no significant difference was observed between uTF levels for current cigarette smokers $(10.0$ $\mathrm{ng} / \mathrm{ml}(7.0-14.0), \mathrm{n}=25)$ and non-smokers $(9.0 \mathrm{ng} / \mathrm{ml}(6.0-12.0), \mathrm{n}=30)$.

\section{Cellular debris}

There was no difference in uTF activity between samples prepared in the usual manner and those subjected to a precentrifugation step to remove cellular debris (data not shown). Thus the presence of cellular debris had no effect on uTF activity.

\section{Diurnal and daily variation}

Samples were obtained at 8 am (zero time) and then at three hourly intervals for 15 hours. There was a trend for samples collected at 0 , 12 , and 15 hours to have higher activity than those collected at 3, 6, and 9 hours. However, these differences were not statistically significant (data not shown). Similarly, day to day variation in uTF activity over a seven day period was not statistically significant (data not shown).

Effect of blood on urinary tissue factor activity Spiking normal urine with increasing amounts of fresh blood had no effect on the measured amount of uTF (data not shown). These results suggest that haematuria would have a negligible effect on uTF activity. 


\section{Discussion}

The inherent variability of the $\mathrm{uTF}$ assay system previously employed ${ }^{14151718}$ has largely contributed to the wide ranges of UTF activity reported in these studies. Since uTF is present on membrane derived vesicles, ${ }^{21}$ variations in availability of tissue factor to the assay system were thought to account for a significant proportion of this variation. The preprocessing step used in the assay described here first concentrates the particulate material by high speed centrifugation, ensuring that all vesicles are sedimented. Solubilisation of the pellet with the detergent BOG ensured that all tissue factor present was made available for assay. This procedure markedly increased the reproducibility of the test procedure.

In our previous studies, ${ }^{14} 151718$ we used Prothromplex (PT, a commercially available concentrate of factors II, VII, and X) as a source of factor X. We noted, however, that PT may undergo autoactivation and that we could not control the final concentration of the reagents in the assay system. There was also the potential for thrombin generation in the assay. We therefore attempted to overcome these problems by using purified clotting factors, recombinant factor VIIa and factor X, and determining the optimal concentration for each factor. The optimum $\mathrm{pH}$ and ionic strength for the uTF assay were also established.

Previous studies have shown that $\mathrm{uTF}$ is relatively unstable on storage. Carty et al showed a fall in UTF activity after 13 days at $4^{\circ} \mathrm{C}$, after 10 days at room temperature and after only four days at $-20^{\circ} \mathrm{C} .{ }^{14}$ Although there are limited data in the literature about the stability of uTF, these results agree with those reported earlier for "prothrombinase" activity in the urine. Matsumura and von Kaulla ${ }^{12}$ found that urine began to lose procoagulant activity after one day of storage at room temperature and after three days at $-20^{\circ} \mathrm{C}$.

Freezing urine could be a major cause of instability. Bach et al showed that freezing and thawing either cause internal reorientation of the vesicles towards the tissue factor or trap the tissue factor within the associated vesicles. ${ }^{22}$ In either case, not all the tissue factor would be available to factor VII and therefore not all the coagulant activity will be measured. These workers have also shown that digestion of tissue factor, using subtilisin protease proteolytic enzyme, causes a $50 \%$ loss in activity on frozen storage. Using the presently described preprocessing technique, we re-evaluated the short and long term stability of UTF. The results showed that both the original and detergent processed urine were relatively stable at $4^{\circ} \mathrm{C},-20^{\circ} \mathrm{C}$, and $-72^{\circ} \mathrm{C}$. At room temperature, however, some loss of activity in the original urine samples was observed. rrTF was stable under the same conditions. The relative stability of uTF in the present study tended to exclude the presence of any inhibitor or enzyme in the urine samples that might antagonise or degrade uTF activity.

We observed that uTF activity is positively correlated with the urine concentration. It was therefore apparent that, in order to overcome this potential source of variability, uTF activity should be corrected for urine concentration. Measurement of urinary creatinine has previously been used to correct for urine concentration in measuring retinol binding protein and $\mathrm{N}$-acetyl $\beta$-D-glucosaminidase, and its validity in correcting uTF values was tested in this study. Creatinine was positively correlated with uTF activity and was therefore considered to be a suitable tool for correction. Correction for urine concentration significantly reduced variation in the assay and markedly narrowed the normal range.

The inhibition of uTF activity by specific anti human tissue factor and concanavalin $\mathrm{A}$ has been reported. ${ }^{14}{ }^{1523}$ To confirm this finding, and to validate that the material being measured in our assay was tissue factor, agents known to inhibit tissue factor activity were applied to the assay. These included antibodies to human tissue factor, concanavalin $\mathrm{A}$, a lectin that binds to the saccharide groups of tissue factor ( $\alpha$-methyl mannopyranoside) and thus prevent its activity, ${ }^{24}$ and phospholipase C, which inactivates tissue factor by cleaving associated phospholipid. ${ }^{25}$ uTF activity was markedly inhibited by all these agents. In addition, tissue factor is factor VII dependent and activity in the assay was also blocked by anti-factor VII. These studies therefore confirm that the urinary procoagulant activity is tissue factor.

Increasing age is associated with a hypercoagulable state and one study has reported an increase in monocyte tissue factor activity with age. ${ }^{26}$ We have previously failed to show a correlation between age and $\mathrm{mTF}$ activity, although methodological factors may have accounted for this finding. ${ }^{27}$ The present work agrees with that reported by both Carty and Adamson (unpublished data), who showed no correlation between age and uTF activity. Sex is another variable that may affect uTF levels. In general, gender has not been reported to play a major role in coagulation, although females have been noted to have faster rates of whole blood clotting. ${ }^{28}$ In the present study, there was no difference in UTF activity between males and females. Some animal studies have yielded sex differences. ${ }^{29}$

Smoking may be a major risk for the development of cardiovascular disease $\mathrm{e}^{30-32}$ and correlates with thrombus progression. ${ }^{33}$ Thus hypercoagulable states could occur in otherwise normal subjects. However, subdivision of the normal control group into current cigarette smokers and non-smokers showed that uTF levels in normal subjects are not significantly affected by smoking, a finding which-like the lack of an age and sex effect-has important ramifications for the design of clinical studies.

Urine, especially early morning urine, usually contains cellular debris comprised of subcellular particles or whole cells. If associated with lipid, these have the ability to enhance tissue factor activity. ${ }^{22}$ Erythrocytes for example, contain a "partial thromboplastin" which may be released during haemolysis and affect uTF activity. To address this question, the effect of debris on UTF activity was examined. Since no such effect was seen, no attempts were 
subsequently made to reduce the amount of debris before assay.

Earlier studies suggested that uTF was increased in early morning samples, ${ }^{12}$ whereas others have reported an increase in samples taken during the evening. ${ }^{34}$ The former study, as noted above, measured a prothrombinaselike activity and does not therefore reflect the behaviour of UTF. However, one might expect that the concentration of a substance excreted by the kidney would passively increase as the urine concentration increases and vice versa. When uTF activity was corrected for the concentration of creatinine, no diurnal variation was observed. This finding is important for comparison of normal values with patient groups since it is not always possible to obtain early morning specimens.

Previous studies of day to day changes in uTF activity have been variable. Some showed relatively low variation, ${ }^{12}{ }^{35}$ while in others this was rather more marked. ${ }^{34}$ Despite these differences, it should be noted that they were all carried out on early morning urine and therefore urine concentration might be expected to have a limited effect. Our study confirmed this expectation. No significant difference was observed for early morning urine samples with or without correction for creatinine concentration, although samples that were so corrected had lower coefficients of variation than those without correction ( $5 \% v 12 \%)$.

Haematuria is a common finding in clinical practice and was simulated in the present study by spiking urine with known amounts of human blood. However, this had no significant effect on the measured activity of uTF, in agreement with the findings of others. ${ }^{17}$ The presence of fresh blood may introduce factors which could influence the assay (for example, small amounts of factors VII and $\mathrm{X}$ ). In addition, haemoglobin may artefactually affect chromogenic assays since it absorbs light at the same wavelength as paranitroanaline. However, in the present study, results obtained from blank wells containing urine but no factor $\mathrm{X}$ were subtracted from the test well results.

Laboratory tests for clinical use should ideally be relatively cheap, reasonably sensitive, and technically simple. The use of urine as the test sample is also attractive since it is generally plentiful and easy to obtain. The measurement of uTF described here fulfils these criteria and would therefore be an ideal clinical test if its diagnostic or prognostic value could be demonstrated.

In conclusion, we have developed and optimised an assay for measuring uTF activity. Factors that might affect uTF activity and which may have contributed to the wide range of UTF values previously observed have been addressed. Specific studies in patients with bladder, prostate, breast, and colorectal cancer are currently in progress.

1 Trousseau A. Phlegmasia alba dolens. In: Clinique medicale de l'Hotel de Paris. Paris: Balliere, 1865:654.

2 Sun NCJ, McAfee WM, Hum GJ, et al. Hemostatic abnormalities in malignancy: a prospective study of one hundred eight patients. Part 1. Coagulation studies. Am f Clin Pathol
1979;71:10-16.
3 Barlow GH, Firestone SL, Robbins KC. Identification of the plasminogen activator(s) produced by the transformed liver cell line SK-HEP-1. Thromb Res 1983;32:29-34.

4 Mussoni L, Conforti G, Gambacorti-Passerini C, et al. Procoagulant and fibrinolytic activity of human ovarian carcinoma cells in culture. Eur f Cancer Clin Oncol 1986;22: $373-80$

5 Gordon SG, Franks JJ, Lewis B. Cancer procoagulant: A factor $\mathrm{X}$-activating procoagulant from malignant tissue. Thromb Res 1975;6:127-37.

6 Dover R, Goeting NLM, Taylor I, et al. Factor X-activating activity in patients with colorectal carcinoma. Br F Surg 1987;74:1122-4.

7 Rickles FR, Rick PD. Structural features of salmonella typhimurium lipopolysaccharide required for activation of tissue factor in human mononuclear cells. $\mathcal{f}$ Clin Invest 1977;59:1188-95.

8 Lorenzet R, Peri G, Locati D, et al. Generation of procoagulant activity by mononuclear phagocytes: A possible mechanism contributing to blood clotting activation within malignant tissues. Blood 1983;62:271-3.

9 Edwards RL, Rickles FR, Cronlund M. Abnormalities of blood coagulation in patients with cancer. Mononuclear cell tissue factor generation. F Lab Clin Invest 1981;98:91728.

10 Rickles FR, Edwards RL, Barb C, et al. Abnormalities of blood coagulation in patients with cancer. Fibrinopeptide A generation and tumor growth. Cancer 1983;51:301-7.

1 Grunke W. Studien uber die Blutgerinnung mit besonderer die Gerinnung haemophilen Blutes. Z Gesamte Exp Med 1835;96:512-16.

12 Matsumura T, von Kaulla KN. Procoagulant content of human urine in health and disease. Am f Clin Pathol 1968; 50:198-210

13 Aoki N, von Kaulla KN. The procoagulant in human urine: purification, assay and some biochemical and physiological properties. Thromb Diath Haemorragica 1966;9:586-605.

14 Carty N, Taylor I, Roath OS, et al. Urinary tissue factor in malignancy. Thromb Res 1990;57:473-8.

15 Carty N, Taylor I, Roath OS, et al. Urinary tissue factor activity in colorectal disease. Br F Surg 1990;77:1091-4.

16 Matsuda M, Aoki N, Kawaoi A. Localization of urinary procoagulant in the human kidney. Kidney Int 1979;15:61217.

17 Adamson AS, Francis JL, Roath OS, et al. Urinary tissue factor levels in transitional cell carcinoma of the bladder. $\mathcal{F}$ Urol 1992;148:449-52.

18 Adamson AS, Francis JL, Witherow RO, et al. Urinary tissue factor in prostatic carcinoma. A potential marker of metastatic spread? Br F Urol 1993;71:587-92.

19 Carson SD. Continuous chromogenic tissue factor activity assay: comparison to clot-based assays and sensitivity 379-87.

20 Carson SD, Konigsberg WH. Lipid activation of coagulation factor iii apoprotein (tissue factor) - reconstitution of the protein-membrane complex. Thromb Haemost 1980;44: 12-15.

21 Wiggins R, Glatfelter A, Kshirsagar B, et al. Lipid microvesicles and their association with procoagulant activity in urine and glomeruli of rabbits with nephrotoxic nephritis. Lab Invest 1987;56:264-72.

22 Bach R, Gentry R, Nemerson Y. Factor VII binding to tissue factor in reconstituted phospholipid vesicles: induction of cooperativity by phosphatidylserine. Biochemistry 1986;25: 4007-20.

23 Matsuda M, Aoki N. Purification and characterization of procoagulant in human urine. Thromb Res 1978;13:31124.

24 Zacharski LR, Rosenstein R, Phillips PG. Concanavalin A inhibition of tissue factor (thromboplastin) activity. Blood 1974;44:783-7.

25 Pusey ML, Mende TJ. Studies on the procoagulant activity of human amniotic fluid. 2. The role of factor VII. Thromb Res 1985;39:571-85.

26 Calmus Y, Robert A. Increase in monocyte procoagulant activity with age. Thromb Res $1986 ; 41: 133-6$.

27 Parmar J, Taylor I, Roath OS, et al. Procoagulant activity in whole blood from patients with breast and colorectal cancer. Blood Coagul Fibrinolysis 1990;1:127-32.

28 Mellor H, Taylor I, Roath OS, et al. Whole blood procoagulant activity in breast and colorectal cancer. $\mathcal{F}$ Clin Pathol 1989;42:489-94.

29 Amlie E, Lyberg T, Kaplun A, et al. Thromboplastin activity of mouse peritoneal macrophages. Thromb Res 1981;24:6171

30 Becker CG, Dubin T. Activation of factor XII by tobacco glycoprotein. F Exp Med 1977;146:457-67.

31 van Der-Salm P, Ubachs HM, van Wersch JW. Cord blood clotting factors in neonates of smoking and non-smoking mothers. Int $\mathcal{F}$ Clin Lab Res 1994;24:177-9.

32 Genest J, Cohn JS. Clustring of cardiovascular risk factor: targeting high-risk individuals. Am $\mathcal{f}$ Cardiol 1995;76:8-20.

33 Krupski WC, Bass A, Dilley RB, et al. Propagation of deep venous thrombosis identified by duplex ultrasonography. $\mathcal{F}$ Vasc Surg 1990;12:467-75.

34 Joist H, Alkjaersig N. Uroplastin, its nature and its excretion pattern in health and certain disease states. Thromb Diath pattern in health and certain

35 Matsumura T, Hutt MP, von Kaulla $\mathrm{KN}$. Urinary procoagulant activity and its relation to kidney function. Nephron 1970;7:165-77. 